\title{
THE ARMED CITIZEN IN THE EARLY REPUBLIC
}

\author{
Robert E. Shalhope* \\ INTRODUCTION
}

Over the past quarter century concerns about the private possession and use of firearms in the United States have greatly intensified. Indeed, citizens with alternative views of "what America is and ought to be" seem to be waging a great American gun war. ${ }^{1}$ This "war," whose operations range from polite public forums to tragic confrontations between individual citizens and the police, finds both sides arrayed behind differing interpretations of the second amendment. Citizens anxious to protect the individual's right to possess firearms stress the "right to bear arms" portion of the amendment. Those concerned with collective rights and communal responsibilities, in contrast, emphasize the "well regulated Militia" phrase in their attempt to gain restrictive gun legislation. Each group rests its case upon an appeal to history. In fact, both sides frequently draw upon the same historical data to support opposing views. ${ }^{2}$ Unfortunately, in their efforts to promote disparate views, these polemicists have obscured the historical context within which the second amendment originated.

\footnotetext{
Copyright (C) 1986 by Law and Contemporary Problems

* Professor of History, University of Oklahoma.

1. Bruce-Biggs, The Great American Gun War, 45 Pub. InTerest 37, 61 (1976).

2. Inter alia, the following articles interpret the second amendment to guarantec an individual right to arms: Caplan, Restoring the Balance: The Second Amendment Retisited, 5 Fordiam Urb. I. Rev. 31 (1976); Halbrook, The Jurisprudence of the Second and Fourteenth Amendments, 4 GEo. MAsON U.L. RFv. 1 (1981); Hardy \& Stompoly, Of Arms and the Law, 51 CHI.-Kent L. Rev. 62 (1974); Whisker. Histmical Development and Subsequent Erosion of the Right to Keep and Bear Arms, 78 W. VA. L. REv. 171 (1975). The following discussions reach the opposite position from what are essentially the same historical materials: G. Newton \& F. Zimring, Firearms and Violence in American Life (1970); Levin, The Right to Bear Arms: The Development of the American Experience. 48 CHI.-KENT L. REv. 148 (1971); Rohner. The Right to Bear Arms: A Phenomenon of Constitutional History. 16 CATH. U.L. REv. 53 (1966): Weatherup, Standing Armies and Armed Citizens: An Analysis of the Second Amendment, 2 Hastings Const. L.Q. 961 (1975).

In recent years the bulk of the literature has tended to support the individual right position. Se?. e.g., Staff of Subcomm. on the Constitution of Senate Comm. on the Judiciari, 97th Cong.. 2D Sess., The Right to Keep and Bear Arms (Comm. Print 1982); Caplan, The Right of the Indiridual to Bear Arms, 4 Det. C.L. Rev. 789 (1982); Dowlut, The Right to Arms: Does the Constitution or the Predilertion of Judges Reign?, 36 OkLa. L. Rev. 65 (1983); Gardiner, To Preserve Libert-t Look at the Right to Keet) and Bear Arms, 10 N. Ky. L. Rev. 63 (1982); Halbrook, To Keep and Bear Their Private Arms: The Adoption of the Second Amendment (1787-1791), 10 N. KY. L. Rev. 13 (1982); Kates. Handgun Prohibition and the Original Meaning of the Second Amendment. $82 \mathrm{MicH}$. L. REv. 204 (1983); Malcolm. The Right of the Prople to Keep and Bear Arms: The Common Law Tradition, 10 Hastings Const. L.Q. 285 (1983).
} 
To grasp the meaning of the amendment, as well as the beliefs of its authors, it is necessary to understand the intellectual environment of late eighteenth-century America. Attitudes toward an armed citizenry in that time had roots in classical philosophy, but drew most fully upon a tradition of "republicanism" received from Niccolo Machiavelli through such intermediaries as James Harrington and James Burgh. ${ }^{3}$ The belief system which emerged from the thought of these men joined the twin themes of personal right and communal responsibility. In this belief system the collective right to arms was not antithetic to that of the individual, but rather inclusive of it, indeed, deduced from it. This integration of the individual and the community has escaped modern antagonists, but it is essential to understanding the second amendment and the role of the armed citizen in the early republic.

This article analyzes the influence of republican ideas in the political culture of early America. By focusing on arms, the individual, and society from an eighteenth-century perspective rather than a twentieth-century one, it attempts to recapture the relationship between the individual and the community characteristic of the early republic. Such an approach should provide useful insights into the beliefs of the founders, the intent of the second amendment, and the legacy of the nineteenth century to the modern gun controversy.

\section{II}

\section{The Relationship Between Arms and Society in RePublican TheORY}

Within the last several decades scholars have recognized the centrality of republicanism, a distinctive universe of ideas and beliefs drawn primarily from the libertarian thought of the English commonwealthmen, in shaping the attitudes of late eighteenth-century Americans. ${ }^{4}$ The fear of standing armies and the exaltation of a militia consisting of the ordinary citizenry are two important elements of republicanism which have received considerable attention. There is an equally important theme, however, which has largely been ignored except for the work of Pocock: the vital interrelationship linking arms, the individual, and society. 5 Therefore, to understand better the origins of the second amendment, this section analyzes the role of the armed citizen within libertarian thought as well as the manner in which Americans integrated this theme into their perception of republicanism.

3. For a discussion of these classical roots, see Halbrook, The Second Amendment as a Phenomenon of Classical Political Philosophy, in Firearms and Violence: Issues of Public Policy 363-83 (I). Kalles ed. 1984).

4. This literature is reviewed in Shalhope, Toward a Republican Sinthesis: The Emergenc' of an Linderstanding of Republicanism in American Historiography, 29 WM. \& M.tR Q $49-80$ (1972), and Shalhope, Republicanism and Early American Historiography, 39 WM. \& MARI Q. 334-56 (1982).

5. This theme appears throughout J. Pocock, The Machiavelian Moment: Fiorentink: Political Thought and the Atlantic Republican Tradition (1975). 
To comprehend libertarian beliefs regarding the relationship between arms and society one should begin with the Florentine tradition upon which republican thought so strongly depended. ${ }^{6}$ This tradition emanated from Niccolo Machiavelli's idealization of the citizen-warrior as the essential foundation of a republic. To Machiavelli the economic independence of the citizen and his ability and willingness to become a warrior were the most dependable protections against corruption. From these basic ideas he fashioned a sociology of liberty dependent upon the place of arms in society: Political conditions must allow every citizen to have arms; moral conditions must encourage all citizens to defend their republic with enthusiasm; and economic conditions must guarantee the citizen-soldier a livelihood upon leaving the army. The interrelation of arms and civic virtue was central to Machiavelli's thought and it fostered a belief in the inseparable nature of arms and a full array of civil rights. To prevent some citizens from possessing arms while allowing others this privilege constituted both a grievous breach of personal freedom and the erosion of a vital safeguard against tyranny.

The same themes surfaced (antithetically) in the philosophy of the French absolutist Jean Bodin. To him the widespread ownership of arms constituted an essential difference between the authoritarian monarchy he favored and popular government. ${ }^{7}$ The latter depended upon, and therefore encouraged, the armament of its individual citizens. Monarchs, on the other hand, only risked disaster by allowing commoners to arm: "[I]t is to be feared that they will attempt to change the state, to have a part in the government." 8 In a monarchy, therefore, "the most usual way to prevent seditions, is to take away the subjects' arms." Although he saw individual arms possession as the source of political unrest, Bodin's reason for opposing popular possession of arms was thus identical to Machiavelli's for supporting it: the power that the possession of arms might give the people relative to their governors.

Speaking from a value system much closer to Machiavelli's than Bodin's, Sir Walter Raleigh agreed with this point, suggesting that among the basic principles of the tyrant was "to unarm his people of weapons, money, and all means whereby they resist his power."' of power, Raleigh amplified this point: "To unarm his people, and store up their weapons, under pretense of keeping them safe, and having them ready when service requireth, and then to arm them with such, and as many as he shall think meet, and to commit them to such as are sure men." 11

These views, along with the Florentine tradition, were reiterated in light of changing conditions in the second half of the seventeenth century by English

6. The discussion of Niccolo Machiavelli which follows in the text is drawn from J. Pocock. supra note 5, at 199-213, 290-92.

7. J. Bodin, The Six Bookes of a Commonweale 542, 599-614, 605 (K. McRac cd. 1962).

8. Id. at 605 .

9. Id. at 542 .

10. 8 W. Raleigh, The Works of Sir Walter Raleigh, Kt. Now First Colifictid: To Winch Are. Prefixed the lives of the Author, by Oldoys and Bircu 22 (Oxford 1829).

11. Id. at 25 . 
libertarian authors such as Marchamont Nedham. Believing that a republic thrived only if its citizens were familiar with the use of arms, Nedham felt that the popular possession of arms was no less indispensable than the regular election of magistrates and representatives. ${ }^{12}$

Most important to the development of this viewpoint, at least in the light of later American attitudes, was the contribution of James Harrington. ${ }^{13}$ Like Machiavelli he believed that the preservation of popular and republican institutions depended upon the continued existence of a "virtuous" citizenry. Moreover, he also defined the virtuous citizen in terms of his possession of arms and his self-reliant willingness to use them in defense of self, liberty, and property. Harrington's innovation, however, lay in joining land ownership with the possession of arms as the twin bases of virtuous citizenship. Because he was both armed and landed, Harrington's virtuous citizen had the necessary independence to maintain his life, liberty, and property against all who would deprive him of them. From Harrington, libertarians came to conceptualize civic virtue in terms of the armed freeholder: upstanding, courageous, self-reliant, individually able to repulse outlaws and oppressive officials, and collectively able to overthrow domestic tyrants and defeat foreign invaders.

Subsequent authors built upon Harrington's intellectual foundation by integrating the subject of arms to the basic themes of power and oppression which permeated libertarian thought. John Trenchard and Walter Moyle, in an attack upon standing armies, elaborated upon the theme that citizens must jealously guard their liberties. Free nations, they warned, never maintained "any Soldiers in constant Pay within their Cities, or even suffered any of their Subjects to make War their Profession."14 Those nations knew "that the Sword and Sovereignty always march hand in hand, and therefore they trained their own citizens and the Territories about them perpetually in Arms, and their whole Commonwealths by this means became so many several formed Militias."'15 Further,

a general Exercise of the best of their People in the use of Arms, was the only bulwark of their Liberties; this was reckon'd the surest way to preserve them both at home and abroad, the People being secured thereby as well against the Domestick Affronts of any of their own Citizens, as against the Foreign Invasions of ambitious and unruly Neighbours. ${ }^{16}$

The idea that citizens must have the capability to protect themselves from their rulers played an important role in the essay of Trenchard and Moyle. Without this ability citizens might lose their liberties and live in tyranny. "It's

12. 103 Mercurius Politicus 1609-13 (London, May 20-27, 1652).

13. The discussion of James Harrington which follows in the text draws upon J. Pocock, supra note 5, at 383-400; see also J. Harrington, The Political Works of James Harrington (J. Pocock ed. 1977).

14. J. Trenchard \& W. Moyle, An Argument Shewing, That a Standing Arm Is Inconsistent with a Free Government, and Absolutely Destructive to the Constitution of THF ENGLiSH MONARCHy 7 (London 1697).

15. Id.

16. Id. 
the misfortune of all Countries, that they sometimes lie under a unhappy necessity to defend themselves by Arms against the Ambition of their Governours, and to fight for what's their own." 17 If those in government ignored reason, the people:

must patiently submit to [their] Bondage, or stand upon [their] own Defence; which if [they] are enabled to do, [they] shall never be put upon it, but [their] Swords may grow rusty in [their] hands; for that Nation is surest to live in Peace, that is most capable of making War; and a Man that hath a Sword by his side, shall have least occasion to make use of it. ${ }^{18}$

Andrew Fletcher's warning, "he that is armed, is always the master of the purse of him that is unarmed," 19 lent subtle support to Trenchard and Moyle's suspicion of governmental authority, which became a central element in libertarian thought.

In Cato's Letters Trenchard and Thomas Gordon integrated the idea of an armed citizenry with the eternal tension libertarians perceived between the realms of power and liberty. They said, "The Exercise of despotick Power is the unrelenting War of an armed Tyrant upon his unarmed Subjects: It is a War of one Side, and in it there is neither Peace nor Truce." 20 Rulers must be restrained by their subjects. An unarmed populace passively fosters their leaders' natural tendency toward oppression for "Men that are above all Fear, soon grow above all Shame." 21

While those authors often discussed the people as a body set off against their rulers, others emphasized the individual citizen's right to defend himself against vicious fellow citizens as well as corrupt authorities-both banes of any republican society. This belief became manifest in observations by Cesare Beccaria and Thomas Paine. In his discussion of the "false ideas of utility,"22 Beccaria expounded upon the wrongheaded nature of laws disarming the populace. He concluded that "such laws make things worse for the assaulted and better for the assailants; they serve rather to encourage than to prevent homicides, for an unarmed man may be attacked with greater confidence than an armed man." 23 A decade later Paine echoed these sentiments when he observed that "the peaceable part of mankind will be continually overrun by the vile and abandoned, while they neglect the means of self defence." $2+$ For Paine, "the supposed quietude of a good man allures the ruffian; while on the other hand, arms like laws discourage and keep the invader and the plunderer in awe, and preserve order in the world as well as property." 25 To protect themselves, responsible citizens must arm themselves. American colonists

17. Id. at 12 .

18. Id. at 7 .

19. A. Fletcher, A Discourse of Government with Relations to Militias, in The Political Works of ANDREW FleTCHER, ESQ. (London 1737).

20. $1 \mathrm{~J}$. Trenchard \& T. Gordon, Cato's letters: Or, Essays on liberty, Cinil and Religious, and Other Important Subjects 189 (London 1755).

21. Id. at 255.

22. C. Beccaria, An Essay on Crimes and Punishments (1764).

23. Id. at $87-88$.

24. I T. Paine, The Writings of Thomas Paine 56 (M. Conway ed. 1894-1896 \& reprint 1967).

25. Id. at 56 . 
clearly articulated this belief in the months following the arrival of British troops in Boston on October 1, 1768. Demanding their rights as British citizens, "to whom the privilege of possessing arms is expressly recognized by the Bill of Rights," 26 Bostonians claimed that it was

a natural Right which the people have reserved to themselves, confirmed by the Bill of Rights, to keep arms for their own defence; and as Mr. Blackstone observes, it is to be made use of when the sanctions of Society and law are found insufficient to restrain the violence of oppression. ${ }^{27}$

Yet the philosophers of republicanism were not blind to the desirability of disarming certain elements within their society. The right to arms was to be limited to virtuous citizens only. Arms were "never lodg'd in the hand of any who had not an Interest in preserving the publick Peace . . . ."28

James Burgh further refined the concepts of opposition to standing armies, dependence upon militias, and the need for the citizen to be armed in his own self defense in his Political Disquisitions, ${ }^{29}$ which proved particularly useful to Americans as they articulated their vision of republicanism. Like his predecessors, Burgh stressed the relationship between arms and power in a society: "Those, who have the command of the arms in a country, says Aristotle, are masters of the state, and have it in their power to make what revolutions they please." 30 Thus, "there is no end to observations on the difference between the measures likely to be pursued by a minister backed by a standing army, and those of a court awed by the fear of an armed people." 31 Burgh linked the very nature of society to whether or not individual citizens had arms and were vigorous in their use:

No kingdom can be secured otherwise than by arming the people. The possession of arms is the distinction between a freeman and a slave. He, who has nothing, and who himself belongs to another, must be defended by him, whose property he is, and needs no arms. But he, who thinks he is his own master, and has what he can call his own, ought to have arms to defend himself, and what he possesses; else he lives precariously, and at discretion. ${ }^{32}$

Burgh's work epitomized the pessimism with which the English libertarians increasingly viewed their own people and, consequently, their society. Following Machiavelli and Harrington, the English libertarians perceived a dynamic relationship between the possession of arms and the spirit and character of the people. The hallmark of virtuous republican citizenship, Burgh reemphasized, was the individual's ability and willingness

26. "A Journal of the Times" for February 6, 1769, printed in the Boslon Eüening-Post, April 3. 1769.

27. "A Journal of the Times" for March 27, 1769, printed in the Boston Evening-Post. May 25, 1769.

28. J. Trenchard \& W. Moyle, supra note 14 , at 7 . Nedham similarly declared that arms should not be "in the hands of any but such as have an Interest in the Publick." Merctirius Politicus, supra note 12 , at 1610 .

29. 2 J. Burgh, Political Disquisitions: Or, an Enquiry into Public Errors, Defects, and) Abuses (London 1774).

30. Id. at 345 (footnote omitted)

31. Id. at 476 .

32. Id. at 390 . 
to arm himself in defense of his person, his property and his state. Consequently, Burgh bewailed what he saw as the moral deterioration of English society. Interested only in luxury and commerce, Englishmen had surrendered their arms: "The common people of England . . . having been long used to pay an army for fighting for them, had at this time forgot all the military virtues of their ancestors." 33

Thus Burgh joined the long line of English libertarians who, from Harrington's time, had grieved over what they perceived as the loss of virility and virtue within their society. An increasingly luxury-loving people had ceased to arm themselves and voluntarily abdicated their martial responsibilities to professionals. True virtue sprang from the agrarian world of self-sufficient farmers, which no longer existed in England. With its demise went all opportunity for a virtuous republic. Libertarians could, however, cling to one hopeful sign: America remained an agrarian society of armed, self-sufficient husbandmen. There, liberty's flame continued to burn brightly.

Americans quickly took up this flattering view of their society. Throughout the revolutionary period and beyond they continued to view the armed husbandman as both the quintessential element and indispensable safeguard in a healthy, virtuous republican state. ${ }^{34}$ James Madison employed this theme in the Federalist Papers. ${ }^{35}$ Noting "the advantage of being armed, which the Americans possess over the people of almost every other nation," he claimed that in Europe. "the governments are afraid to trust the people with arms." 36 Several decades later Timothy Dwight reiterated this view when he wrote that:

[T]o trust arms in the hands of the people at large has, in Europe, been believed . . . to be an experiment fraught only with danger. Here by a long trial it has been proved to be perfectly harmless . . . . If the government be equitable; if it be reasonable in its exactions; if proper attention be paid to the education of children in knowledge and religion, few men will be disposed to use arms, unless for their amusement, and for the defence of themselves and their country. ${ }^{37}$

Joel Barlow clearly articulated the vital relationship of armed citizens to American republican thought. For him, America's strength rested in "making every citizen a soldier, and every soldier a citizen; not only permitting every man to arm, but obliging him to arm."38 In Europe this idea "would have gained little credit; or at least it would have been regarded as a mark of an uncivilized people, extremely dangerous to a well ordered society."39 Quite

33. Id. at 415 .

34. For an analysis of these attitudes, see Shalhope, The Ideological Origins of the Second Amendment. 69 J. Aм. Hist. 599, 605-07 (1982).

35. The Federalist No. 46 [45], at $321-22$ (J. Madison) (J. Cooke ed. 1961). (This essav, originally published as number 45 , appears as number 46 in the Cooke edition. For an explanation of this discrepancy, see pp. xviii-xix in the Cooke edition.)

36. Id.

37. I T. Dwight, Travels in New-England and New-York xiv (London 1823).

38. J. Barlow, Advice to the Privileged Orders in the Several. States of Europe: Resulting from the Necessity and Propriety of a General Rfiolution in the Principle of Government, Parts I And II, at 16 (London 1792, 1795 \& reprint 1956).

39. Id. 
the reverse characterized America where, "it is because the people are civilized, that they are with safety armed."40 Such was the value of freedom and equality that Americans' "conscious dignity, as citizens enjoying equal rights," precludes any desire "to invade the rights of others." 41

[T] he danger where there is any from armed citizens, is only to the government, not to the society and as long as they have nothing to revenge in the government (which they cannot have while it is in their own hands) there are many advantages in their being accustomed to the use of arms, and no possible disadvantage. ${ }^{42}$

To the morally uplifting regime of free institutions Barlow contrasted despotisms characterized by professional soldiers

who know no other God but their king; who lose all ideas of themselves, in contemplating their officers; and who forget the duties of a man, to practise those of a soldier,-this is but half the operation: an essential part of the military system is to disarm the people, to hold all the functions of war, as well the arm that executes, as the will declares it, equally above their reach. ${ }^{43}$

Then, by integrating Adam Smith's contention that individuals who lost their martial spirit suffered "that sort of mental mutilation, deformity and wretchedness which cowardice necessarily involves in it"44 with his own beliefs, Barlow articulated the vital nature of armed citizens in American republican thought: A government that disarmed its people "palsies the hand and brutalizes the mind: an habitual disuse of physical forces totally destroys the moral; and men lose at once the power of protecting themselves, and of discerning the cause of their oppression." 45 Only the individual capable of defending himself with arms if necessary possessed the moral character to be a good republican citizen. In democracies "the people will be universally armed: they will assume those weapons for security, which the art of war has invented for destruction." 46 A republican society might retain its vigor and virtue only so long as its individual citizens possessed arms and the capability of using them in the defense of themselves, their property, and their society.

This theme permeated the political observations of the eighteenth century. During the struggle over the ratification of the Constitution, Federalists and anti-Federalists alike had linked the preservation of liberty to an armed populace. Richard Henry Lee considered it "essential that the whole body of the people always possess arms, and be taught alike, especially when young, how to use them." 47 In his defense of the Constitution, Noah Webster echoed Madison's theme: "The supreme power in America cannot enforce unjust law

40. Id.

41. Id. at 17 .

42. Id.

43. Id. at 45 .

44. 2 A. Smith, An Inquiry into the Nature and Causes of the Wealth of Nations 373 (London 1776). For an excellent discussion of Adam Smith's attitudes toward the relationship between martial spirit and the public character, see D. Winch, Adam Smith's Politics: An Essay in Historiographic Revision 103-20 (1978).

45. J. BARLow, supra note 38 , at 45.

46. Id. at 46 .

47. R. Lee, Letters from the Federal Farmer to the Republican 124 (W.H. Bennell ed. 1978) (1st ed. n.p. 1777-1778). 
by the sword; because the whole body of the people are armed, and constitute a force superior to any band of regular troops that can be, on any pretence, raised in the United States." 48 Thomas Jefferson, while not a participant in the ratification process, revealed a depth of feeling transcending politics with regard to the relationship among liberty, arms, and the character of the individual republican citizen. Writing to his nephew, Peter Carr, Jefferson advised that "health must not be sacrificed to learning." 49 A few hours each day should be set aside for physical exertion. "As to the species of exercise, I advise the gun. While this gives a moderate exercise to the body, it gives boldness, enterprize [sic], and independance [sic] to the mind."50 In contrast, he believed that "[g]ames played with the ball and others of that nature, are too violent for the body and stamp no character on the mind. Let your gun therefore be the constant companion of your walks." 51 Here is perhaps the clearest indication that Americans perceived a vital link between the gun and the character of the individual citizen.

\section{III \\ The Bill of Rights}

When James Madison and his colleagues drafted the Bill of Rights, they did so at a time when Americans felt strongly about protecting individual rights from a potentially dangerous central government. Regarding the place of arms within their society, the drafters firmly believed in two distinct principles: (1) Individuals had the right to possess arms to defend themselves and their property; and (2) states retained the right to maintain militias composed of these individually-armed citizens. Further, the drafters felt that professional armies should exist only in wartime and that, in any event, the military should always be subordinate to civilian control.

These principles had been clearly articulated in the several state bills of rights as well as in the amendments to the Constitution proposed by the various state ratifying conventions. The Pennsylvania Bill of Rights, for example, stated:

That the people have a right to bear arms for the defense of themselves and the state; and as standing armies in the time of peace are dangerous to liberty, they ought not to be kept up; And that the military should be kept under strict subordination to, and governed by, the civil power. ${ }^{52}$

In their ratifying convention, New Hampshire men ignored the militia issue, but did claim that "no standing Army shall be Kept up in time of Peace

48. Webster, An Examination into the Leading Principles of the Federal Comstitulion, in PaMPHI.ETS on the Constitution of the United States 56 (P. Ford ed. 1971).

49. T. Jefferson, Thomas Jefferson to Peter Cam, August 19, 1785, in 8 The Papers of lilomas JefFerson 405, 407 (J. Boyd ed. 1950-1982) [hereinafter cited as JefFerson Papers].

50. Id.

51. Id.

52. The frepral and State Constitutions, Colonial Charters, and Other Organic Ialis of tile States, lerritories and Colonies Now or Heretofore forming the. Uniteis States of America 3083 (F. Thorpe ed. 1909) [hereinafter cited as F. THORPE]. All of the state bills of rights appear in this collection. 
unless with the consent of three fourths of the Members of each branch of Congress, nor shall Soldiers in Time of Peace be quartered upon private Houses without the consent of the Owners." 53 Then, they offered a separate admonition: "Congress shall never disarm any Citizen unless such as are or have been in Actual Rebellion." 54

The Virginia convention exclaimed:

That the people have a right to keep and bear arms; that a well regulated Militia composed of the body of the people trained to arms is the proper, natural and safe defence of a free State. That standing armies in time of peace are dangerous to liberty, and therefore ought to be avoided, as far as the circumstances and protection of the Community will admit; and that in all cases the military should be under strict subordination to and governed by the Civil power. ${ }^{55}$

New Yorkers, who suggested over fifty amendments to the Federal Constitution, observed: "That the People have a right to keep and bear Arms; that a well regulated Militia, including the body of the People capable of bearing Arms, is the proper, natural and safe defence of a free state." 56 Pennsylvania's minority report, a widely publicized anti-Federalist tract, was the most specific:

That the people have a right to bear arms for the defence of themselves and their own State, or the United States, or for the purpose of killing game; and no law shall be passed for disarming the people or any of them, unless for crimes committed, or real danger of public injury from individuals; and as standing armies in the time of peace are dangerous to liberty, they ought not to be kept up; and that the military shall be kept under strict subordination to and be governed by the civil power. ${ }^{57}$

The Massachusetts Declaration of Rights claimed that the people had a "right of enjoying and defending their lives and liberties" (Article I) ${ }^{58}$ and "to keep and to bear arms for the common defense" (Article XVII). ${ }^{59}$ This wording caused a number of towns to demand more precise language in order to spell out the individual's right to possess arms in his own defense. The citizens of Northampton, for instance, resolved:

We also judge that the people's right to keep and bear arms, declared in the seventeenth article of the same declaration is not expressed with that ample and manly openness and latitude which the importance of the right merits; and therefore propose that it should run in this or some such like manner, to wit, The people have a right to keep and bear arms as well for their own as the common defence. Which mode of expression we are of opinion would harmonize much better with the first article than the form of expression used in the said seventeenth article. ${ }^{60}$

For their part, inhabitants of Williamsburgh stated:

53. E. Dumbauld, The Bill of Rights: And What It Means Today 182 (1957).

54. Id. at 185 .

55. Id.

56. Id. at 189. New York had the only state amendment that distinguished between keeping and bearing arms. It allowed all citizens to possess arms, but only those with the capability to bear them were asked to do so.

57. Id. at 174. For an excellent analysis of this report, see 2 The Documentary History of the Ratification of the Constitution 617-40 (M. Jensen ed. 1976).

58. $8 \mathrm{~F}$. ThоRPE, supra note 52 , at 1889 .

59. Id. at 1892 .

60. The Popular Sources of Political Authority: Documents on the Massachusetts Constitution of 1780, at 574 (O. Handlin \& M. Handlin eds. 1966). 
Upon reading the 17th Article in the Bill of Rights. Voted that these words their Own be inserted which makes it read thus; that the people have a right to keep and to bear Arms for their Own and the Common defence.

Voted Nemine Contradic.

Our reasons gentlemen for making this Addition Are these. 1st that we esteem it an essential priviledge to keep Arms in Our houses for Our Own Defence and while we Continue honest and Lawful Subjects of Government we Ought Never to be deprived of them. ${ }^{61}$

Influential Americans clearly differentiated individual possession of arms from service in the militia. Samuel Adams offered an amendment at his state's convention that read: "And that the said Constitution be never construed to authorize Congress to infringe the just liberty of the press or the rights of conscience; or to prevent the people of the United States who are peaceable citizens from keeping their own arms." 62 Thomas Jefferson did not even mention the militia in his initial draft of a proposed constitution for the State of Virginia. He did, however, oppose standing armies except in time of actual war. ${ }^{63}$ Then, in a separate phrase, he wrote: "No freeman shall ever be debarred the use of arms." 64 In succeeding drafts he amended this statement to read: "No freeman shall be debarred the use of arms within his own lands or tenements." 65 Clearly, Jefferson believed that the possession of arms could be entirely unrelated to service in the militia.

James Madison believed in balancing individual rights with communal responsibilities. Having buttressed the corporate nature of society with the Constitution, Madison and others set out to protect the individual from the potentially overweening power of the community. When he offered the amendments comprising the Bill of Rights, Madison suggested they be inserted directly into the body of the Constitution in article I, section 9 , between clauses 3 and $4 .{ }^{66}$ He did not separate the right to bear arms from other rights designed to protect the individual; nor did he suggest placing it in section 8 , clauses 15 and 16 , which dealt specifically with arming and organizing the militia. ${ }^{67}$ When preparing notes for an address supporting the amendments, Madison reminded himself: "They relate 1st to private rights"; 68 and when he consulted with Edmund Pendleton, Madison emphasized that "amendments may be employed to quiet the fears of many by supplying those further guards for private rights." 69

61. Id. at 624 .

62. $3 \mathrm{~W}$. Wells, The life and Public Services of Samuel Adams, Being a Narrative of His Acts and Opinions, and of His Agency in Producing and Forwarding the American Revolition 267 (Boston 1865).

63. See 1 Jefferson Papers, supra note 49 , at 344.

64. Id. at 353.

65. Id. at 363 .

66. 12 The Papers of James Madison 201 (R. Rutland ed. 1977).

67. See id. at 193, 201.

68. Id. at 193.

69. Id. at 306-07. 
Others assumed the same stance. Madison's confidant, Joseph Jones, believed the proposed articles were "calculated to secure the personal rights of the people so far as declarations on paper can effect the purpose."70 Tench Coxe, writing as "Pennsylvanian," discussed individual guarantees and then, in reference to the second amendment, maintained that "the people are confirmed by the next article in their right to keep and bear their private arms."71 "Philodemos" exclaimed: "Every freeman has a right to the use of the press, so he has to the use of his arms." 72 Clearly, Madison and his colleagues intended the right to bear arms, like that of free speech or the press, to be a guarantee for every individual citizen whether or not he served as part of the militia.

When Madison and his select committee drafted the Bill of Rights, they did their best to combine briefly the essential elements of the various state bills of rights as well as the many suggestions made by state ratifying conventions. The effort resulted in a good deal of cutting, revising, and synthesizing. ${ }^{73}$ This drafting approach was certainly used with the second amendment, as the committee incorporated two distinct, yet related, rights into a single amendment. ${ }^{74}$

The brief discussion of the amendment in Congress makes clear that the committee had no intention of subordinating one right to the other. ${ }^{75}$ Elbridge Gerry attacked the phrase dealing with conscientious objectors, those "scrupulous of bearing arms," that appeared in the original

70. Id. at 258-59.

71. Fed. Gazette and Philadelphia Evening Post, June 18, 1789, at 2, col. 1.

72. Pennsylvania Gazette (Philadelphia), May 7, 1788, at 3, col. 2.

73. For an excellent analysis of this process, see B. Schwartz, The Great Rights of Mankind: A History of the American Bill of Rights 160-91 (1977).

74. There is nothing incongruous in the second amendment's combination in one article of such distinct, but related, ideas as that of the privately armed citizen and that of a militia composed of citizens bearing their own private arms. In this same manner the first amendment combines the distinct, yet closely related, principles of freedom of religion and separation of church and state with the more remotely related ones of freedom of speech and the press and the right of assembly and petitioning for grievances.

75. This is the manner in which contemporary as well as later 19th-century legal scholars interpreted the amendment. See Kates, supra note 2, at 240-43. Writing in 1829, William Rawle discussed the militia and then stated: "The corollary, from the first position, is, that the right of the people 10 keep and bear arms shall not be infringed. The prohibition is general. No clause in the Constitution could by any rule of construction be conceived to give to congress a power to disarm the people." W. Rawle, A View of the Constitution of the United States of America 125 (2d ed. Philadelphia 1829 \& reprint 1970) (emphasis in original). Fifty years later Thomas Cooley claimed that: "It might be supposed from the phraseology of this provision that the right to keep and bear arms was only guaranteed to the militia; but this would be an interpretation not warranted by the intent." Then, "the meaning of the provision undoubtedly is, that the people, from whom the militia must be taken, shall have the right to keep and bear arms; and they need no permission or regulation of law for the purpose." $\Gamma$. Cooley, The General Principles of Constiturional Law in THE UNITED States OF AMERICA 271 (1880).

In their interpretations of the second amendment various authors have stressed the amendment's wording. Sep supra note 2. It is clear, however, that James Madison and the committee worked toward succinctness. Indeed, Madison's original suggestion read: "The right of the pcople to keep and bear arms shall not be infringed; a well armed and well regulated militia being the best security of a free country: but no person religiously scrupulous of bearing arms shall be compelled to render military service in person." E. Dumbaul.D, supra note 53, at 207. 
amendment. Revealing a libertarian distrust of government, Gerry maintained that the declaration of rights in the proposed amendment "is intended to secured the people against the mal-administration of the Government," and indicated that the federal government might employ the conscientious objector phrase "to destroy the constitution itself. They can declare who are those religiously scrupulous, and prevent them from bearing arms." 76 This would return America to a European-style society in which governments systematically disarmed their citizens. Thomas Scott of Pennsylvania also strenuously objected to this phrase for fear it might "lead to the violation of another article in the constitution, which secures to the people the right of keeping arms." 77

While congressmen firmly believed in the right of individual citizens to possess arms, no consensus existed regarding whether or not these people should be required to bear arms in the militia. One representative declared: "As far as the whole body of the people are necessary to the general defence, they ought to be armed; but the law ought not to require more than is necessary; for that would be a just cause of complaint."78 But another representative observed that "the people of America would never consent to be deprived of the privilege of carrying arms. Though it may prove burdensome to some individuals to be obliged to arm themselves, yet it would not be so considered when the advantages were justly estimated."79 Other congressmen even went so far as to argue that the states should supply firearms to those Americans without them. ${ }^{80}$ Regardless of their voicers' feelings about the militia, such statements clearly revealed an urge to get arms into the hands of all American males between the ages of eighteen and fortyfive, and not to restrict such possession to those in militia service. ${ }^{81}$

While late eighteenth-century Americans distinguished between the individual's right to possess arms and the need for a militia in which to bear them, more often than not they considered these rights inseparable. Observations by Madison, George Washington, Dwight, and Joseph Story provide excellent insight into why it was so natural to combine these two rights into a single amendment.

76. I Annals of Cong. 779 (J. Gales ed. 1789).

77. Id. at 749 .

78. See id. at 1806.

79. Id.

80. See id. at 1807 .

81. This was the opinion of St. George Tucker, one of the leading jurists of the day. When he edited Blackstone's Commentaries, Tucker noted the master's observation that the right of the people to bear arms constituted one of the essential rights necessary to protect life, liberty, and property. His footnote to this section read: "The right of the people to keep and bear arms shall not be infringed. Amendments to C. U. S. [Constitution of the United States] Art. 4, and this without any qualification as to their condition or degree, as is the case in the British government." 1 W" Blackstone, Commentaries 143 n.40 (Philadelphia 1803 \& reprint 1965). In another note Tucker observed that "whosocver examines the forest, and game laws in the British code, will readily perceive that the right of keeping arms is effectually taken away from the people of England." Id. at 144 n.4. Blackstone himself informed us that the "prevention of popular insurrections and resistance to government, by disarming the bulk of the people. . . is a reason oftener meant, than avowed, by the makers of the forest and game laws." 2 id. at 412 (footnote omitted). 
Madison observed that in the case of oppressed Europeans "it is not certain that with this aid alone [possession of arms], they would not be able to shake off their yokes."82 Something beyond individual possession of weapons was necessary:

But were the people to possess the additional advantages of local governments chosen by themselves, who could collect the national will, and direct the national force; and of officers appointed out of the militia, it may be affirmed with the greatest assurance, that the throne of every tyranny in Europe would be speedily overturned, in spite of the legions which surround it. ${ }^{83}$

Similarly, Washington declared: "To be prepared for war, is one of the most effectual means of preserving peace. A free people ought not only to be armed, but disciplined; to which end, a uniform and well-digested plan is requisite." 84

Several decades later, Dwight exalted the right of the individual to possess arms as the hallmark of a democratic society. But he observed: "The difficulty here has been to persuade the citizens to keep arms, not to prevent them from being employed for violent purposes."85 A similar lament characterized the observations of Story, whose Commentaries captured the vital essence of the relationship between armed citizens and the militia. Regarding the second amendment, Story wrote:

The right of the citizens to keep and bear arms has justly been considered, as the palladium of the liberties of a republic; since it offers a strong moral check against the usurpation and arbitrary power of rulers; and will generally, even if these are successful in the first instance, enable the people to resist and triumph over them. And yet, though this truth would seem so clear, and the importance of a well regulated militia would seem so undeniable, it cannot be disguised, that among the American people there is a growing indifference to any system of militia discipline, and a strong disposition, from a sense of its burdens, to be rid of all regulations. How it is practicable to keep the people duly armed without some organization, it is difficult to see. There is certainly no small danger, that indifference may lead to disgust, and disgust to contempt; and thus gradually undermine all the protection intended by this clause of our national bill of rights. ${ }^{86}$

Such observations divulge a fascinating relationship between the armed citizen and the militia. Clearly, these men believed that the perpetuation of a republican spirit and character within their society depended upon the freeman's possession of arms as well as his ability and willingness to defend both himself and his society. This constituted the bedrock, the "palladium," of republican liberty. The militia remained equally important to them, however, because militia laws insured that American citizens would remain armed and, consequently, retain their vigorous republican character. Beyond that, the militia provided the vehicle whereby the collective force of individually-armed citizens might become most effectively manifest. By

82. The Federalist No. 46 [45], at 321-22 (J. Madison) (J. Cooke ed. 1961) (see supra note 35).

83. Id.

84. I Annals of Cong. 933 (J. Gales ed. 1790).

85. I T. Dwight, supra note 37 , at xiv.

86. 3 J. Story, Commentaries on the Constitution of the United States; With a Preliminary Review of the Constitutional History of the Colonies and States, Before the Adoption of THE Constitution 746-47 (Boston 1833) (footnotes omitted). 
consolidating the power of individual Americans, the militia forced those in power to respect the liberties of the people and minimized the need for professional armies, the greatest danger a republican society could face. This belief lay behind Jefferson's oft-quoted statement: "[W] hat country can preserve it's [sic] liberties if their rulers are not warned from time to time that their people preserve the spirit of resistance. Let them take arms." 87 Thus, the armed citizen and the militia existed as distinct, yet dynamically interrelated elements within American thought; it was perfectly reasonable to provide for both within the same amendment to the Constitution.

\section{IV \\ Post-Revolution America and the Importance OF THE INDIVIDUAL}

With the passage of time, the importance of the militia faded in American thought while the image of the privately-armed citizen assumed increased importance. This shift in thought, resulting from changes in perceptions of republicanism during and after the Revolution, has exerted an enormous influence over time and plays a major role in the current discussion of the private ownership of guns.

Many Americans entered the Revolution with the millenial expectation of creating a new republican society comprised of virtuous citizens free of Old World corruption. ${ }^{88}$ During the course of the war, however, American behavior manifested disturbing and disappointing signs of European vices. Public officials and contractors indulged in graft; farmers and merchants displayed greed; many Americans traded with the enemy; and the government had to rely on conscription of men and confiscation of property in order to prosecute the war. ${ }^{89}$ Most important, the militia-the backbone of a republican society-proved ineffective; only the presence of a regular army saved the cause. ${ }^{90}$ Despite these facts, following Yorktown, Americans chose to believe that their victory was a confirmation of their moral strengths. ${ }^{91}$ In 1783 it was public virtue, not its failure, that was crucial. To preserve their millenial vision of the future, Americans could not recognize the reality of the many questionable expedients employed to win the war. Concerned about their failures and anxious about their bequest to posterity, the revolutionary generation redefined its experiences and made them as virtuous and as heroic as they ought to have been. Thus, victory-gained by the fallible, partial, and selfish efforts of most Americans-allowed an entire generation to ignore this unpleasant reality and to claim that it had remained true to the standard of

87. 12 JefFerson Papers, supra note 49, at 356.

88. G. Wood, The Creation of the American Republic, 1776-1787, at $91-124$ (1969).

89. The discussion of the symbolic importance of the militia that follows in the text draws upon C. Royster, A Revolutionary People at War: The Continental Army and American Character. 1775-1783, at 331-68 (1979).

90. Id.

91. Id. 
1775. They offered that standard and the image of a unified, virtuous republican citizenry to future generations.

The impulse to glorify the revolutionary effort led to exaggerated claims of success and helps to explain the significance accorded the militia by Americans in the 1780 's. The popular interpretation of victory in the Revolution ignored the role played by the regular army and reinstated the people's militia as the vital pillar of American virtue and essential to the preservation of the nation's unique republican character. Thus, at the time the Founders drafted the Bill of Rights, reaffirmation of the militia principle seemed important along with the guarantee of arms to the individual. In the face of nineteenth-century developments, however, the symbolic importance of the militia would fade, while that of the armed individual gained increased stature.

Americans of the revolutionary generation had made a profession of virtue and committed their republic to the escape from corruption, but Enlightenment thought taught them that natural laws of social and economic development gripped all societies in an evolutionary process that carried them inevitably from brutal savagery to the decadent civilization of commerce and corruption. ${ }^{92}$ In response, following Harrington's reasoning that commerce could not corrupt so long as it did not overwhelm agrarian interests, Americans believed that in order to accommodate both virtue and commerce a republic must be as energetic in its search for land as it was in its search for commerce. A vast supply of land, occupied by an armed and self-directing yeomanry, might establish an endless reservoir of virtue. This belief is what gave point to Jefferson's observation that "our governments will remain virtuous for many centuries; as long as they are chiefly agricultural; and this will be as long as these shall be vacant lands in any part of America."93 If American virtue was threatened by the increase in commercial activity following the Constitution of 1787 , it could revitalize itself on the frontier through the efforts of the armed husbandman. America might yet escape the evils of history by remaining forever in a "middle state" in which the people were constantly reinvigorated through their contact with nature. The "aggressive virtu of agrarian warriors" could thrive forever on the frontier. ${ }^{94}$ Thus, Americans became caught up in a flight from history into nature.

A violently activist democratic ideology, based on nature's abundance and vitality, emerged in the nineteenth century. ${ }^{95}$ Americans would not have to create their history in closed space, which could only foster decadence and decay. They could perpetually return to youthful vigor on the frontier. There they could begin again and regenerate themselves and their society through

92. For an outstanding analysis of the republican perception of social progress and decay, see $\mathbf{D}$.

McCoy, The Elusive Republic: Political Economy in Jeffersonian America 13-47 (1980).

93. 12 Jefferson Papers, supra note 49, at 442 (letter from Jefferson to James Madison).

94. These observations regarding the tension between commerce and virtue rest upon $\mathrm{J}$. Pocock, supra note 5, at 506-52. The quotation appears id. at 537.

95. For excellent insight into the development of this ideology, see J. WARD, ANDREN JACKSON. SyMbOL For AN AGE (1953). 
heroic combat with the wilderness and its creatures. ${ }^{96}$ The frontiersman gained self-realization through the prideful display of individual prowess and by a manly independence of social or other restraints. The myth of the frontiersman became one of self-renewal or self-creation through acts of violence. Believing in the possibility of regeneration, hunters, Indian fighters, and farmers gradually destroyed the natural conditions that supported their economic and social freedom as well as their democracy of social mobility. Yet the mythology and the value system it spawned survived long after the objective conditions that had justified it disappeared. By this process, the armed individual, free to act on his environment as he saw fit, free to control his own destiny, became an integral part of the nineteenth century's legacy to modern America. It is this inheritance that undergirds the emotional commitment of so many Americans today to the private ownership of guns. This is the legacy with which gun control advocates must contend.

\section{$\mathrm{V}$ \\ ConCLusion}

When lawyers contest the "correct" interpretation of the past, history is often the loser. Angry polarization and distortion, rather than clarification and understanding, can be the result. This is certainly the case with the current argument between those emphasizing the right-to-bear-arms part of the second amendment and those stressing its well-regulated militia phrase. Such contentiousness obscures the Founders' efforts to create a nation that would foster communal responsibilities while at the same time guaranteeing the individual rights of its citizens. It may very well be true that neither the militia nor the armed citizen is appropriate for modern society. In any event today's needs, however urgently they are felt, must not be allowed to obscure our understanding of the origins of the second amendment and, in the process, our understanding of revolutionary America. The second amendment included both of its provisions because the Founders intended both of them to be taken seriously. They intended to balance as best they could individual rights with communal responsibilities.

96. This analysis of the myth of regeneration draws upon M. Rogin. Fathers and Cinidint: Andrew Jackson and the Subjugation of the American Indian (1975), and R. Sigtkin. Regeneration Through Violence: The Mythology of the American Frontifr, 1600-1860 (1973). 


$$
\text { . }
$$

